\title{
Production, Reproduction Performance and Cost Economics of Nellore Brown Lambs Reared under Different Systems of Rearing
}

B. Rangamma, A. Sarat Chandra, N. Rajanna, M. Gnana Prakash, M. Venkateswarlu, Ch. Hari Krishna

10.18805/IJAR.B-4510

\begin{abstract}
Background: To know the production and reproductive performance of Nellore brown lambs under three systems i.e. intensive, semiintensive and extensive system of rearing and which system of rearing was beneficial for the farmer community in terms of cost economics.

Methods: 36 Nellore brown lambs of 3 months age from Livestock Research Station, Mamnoor, Warangal district were randomly allotted to three rearing systems i.e. Intensive (G1), Semi-intensive (G2) and Extensive (G3) system of each 12 animals. The body weight and ADG of lambs in the three systems were recorded fortnightly and calculated the cost economics. The reproductive parameters of ewe lambs were recorded.

Result: From 3-9 months age, the mean gain in body weight $(\mathrm{kg})$ in the $\mathrm{G} 1$ group was significantly $(\mathrm{P}<0.01)$ higher followed by $\mathrm{G} 2$ $(10.95 \pm 0.18)$ and $G 3(9.33 \pm 0.09)$ groups. The mean ADG $(\mathrm{gm})$ was significantly $(P<0.01)$ higher in $\mathrm{G} 1$ group $(75.14 \pm 1.56)$ than $\mathrm{G} 2$ $(60.83 \pm 1.02)$ and $G 3(51.81 \pm 0.47)$ groups. Significant $(P<0.05)$ difference was observed in the mean age at puberty of ewe lambs in the three groups. The mean age at first service was lowest in G1 (329.50 \pm 6.99$)$ followed by G2 (360.17 \pm 6.56$)$ and G3 (385.17 \pm 5.60) groups. The net income (Rs.) obtained from each lamb was 1870.8, 1406.7 and 1217.3, respectively in G1, G2 and G3 groups. The cost per kilogram live weight gain was higher in the G1 group followed by G2 and G3 group.
\end{abstract}

Key words: ADG, Body weight, Economics, Lambs, Systems of rearing.

\section{INTRODUCTION}

Sheep are raised in India on natural vegetation and public grazing lands. Sheep need less labor and provide an alternative source of income for smallholder farmers (Arora et al., 2016). The contribution of small ruminants is very valuable in rural areas (Ramesh et al., 2012). Of the various environmental factors which limit the productivity of sheep and goats, nutrition is by far the most important factor (Devendra, 1980).

Extensive system is the most dominant system of production where the small ruminants are reared on community rangeland during the monsoon and later on stubble grazing on cropped land or forest land. In semiintensive system, animals are allowed to graze on the common property resources or cultivable/fallow land for 812 hours per day and then supplemented with concentrates. The level of supplementation is inversely proportional to the biomass available from the grazing lands and it is generally higher during summer in plains and in winter at high altitudes. The intensive system includes complete stall feeding on cultivated fodders, crop residues and concentrates or compounded feeds or grazing on developed pastures combined with stall feeding. It requires high labour and capital investment and constitutes less than $5 \%$ of the small ruminant production systems. But weather and geographical environments are the most important factors affecting the implementation of a particular rearing system, while
Department of Livestock Production Management, College of Veterinary Science, Sri Venkateswara Veterinary University, Tirupati517502, Andhra Pradesh, India.

Corresponding Author: B. Rangamma, Department of Livestock Production Management, College of Veterinary Science, Tirupati517 502, Andhra Pradesh, India. Email: dr.batthina@gmail.com

How to cite this article: B. Rangamma, A. Sarat Chandra, N. Rajanna, M. Gnana Prakash, M. Venkateswarulu and Hari Krishna, Ch. (): Production, Reproduction Performance and Cost Economics of Nellore Brown Lambs Reared under Different Systems of Rearing. Indian Journal of Animal Research. DOI: 10.18805/IJAR.B-4510.

Submitted: 04-05-2021

Accepted: 04-08-2021

Online: $21-08-2021$

production expense is the most important factor influencing the system's performance (Ocak et al., 2016). Based on the above facts, to know the performance of Nellore brown lambs breed under different systems of rearing the present was planned.

\section{MATERIALS AND METHODS}

\section{Site of the study}

The present study was conducted at Livestock Research Station, Mamnoor, Warangal district, Telangana state situated at an altitude of 290 meters above mean sea level on $79.59 p$ longitudes and $17.9 p$ latitude. The minimum and 
maximum temperature range from 16.2 and $42.9^{\circ} \mathrm{C}$. The average annual rainfall of the area is $994 \mathrm{~mm}$. Some rainfall during the summer and post-monsoon months and it is mainly in the form of thunder storms.

\section{Animals}

Thirty-six (36, $3 \times 12)$ weaned lambs of 3 months of age were selected from the sheep unit, Livestock Research Station, Mamnoor. The lambs were divided into three groups of twelve lambs in each group $(3 \times 12)$ with uniform body weights as possible by using Completely Randomized Design. These 12 lambs (six males and six females in each group) were allocated to each of the rearing system viz., Intensive group (G1), Semi-intensive group (G2) and Extensive group (G3) to study the production performance. The lambs were housed in well- ventilated shed made up of asbestos sheet roofing with morum flooring and maintained under hygienic conditions. The sheds were cleaned every day morning and lime was applied on the floor once every fifteen days. The lambs were provided with bore well water ad libitum for drinking purposes. The waterers were cleaned every day and filled with fresh water in the morning and evening. The lambs were dewormed at the starting of the study. Prophylactic measures against Sheep pox, Enterotoxaemia, Pests des petits ruminants, Bluetongue, Hemorrhagic Septicemia, endo and ectoparasitic infections were carried out as per the institution calendar to ensure animal health condition throughout the study period.

\section{Body weight recording}

The bodyweight of the lambs was recorded at 7.30-8.30 am in the morning before offering feed by using platform balance. The weight of the lambs were recorded at fortnight interval from starting to end of the study.

\section{Average daily gain (ADG)}

The average daily gain (ADG) and feed conversion ratio (FCR) were calculated by using the following formulae.

Average daily gain $(A D G)=$

$$
\frac{\text { Final weight }(\mathrm{kg}) \text { - Inital weight }(\mathrm{kg})}{\text { No. of days of trial }}
$$

\section{Cost economics calculation}

The total cost of experimental diets per quintal were calculated on the basis of prevailing market rates for lambs and feed ingredients. The cost of production per ton of green fodder was taken and for labour cost per minimum wage act of Government of India was taken into account for the calculation of labor cost required for grazing operations.

\section{Experimental procedure}

The study was conducted for a period of more than 1 years from March 2019 to June 2020. All 36 selected lambs for the study was allotted to three rearing systems i.e Intensive (G1), Semi-intensive (G2) and Extensive (G3) system by using Complete Randomized Design (3x20). In G1 group, the lambs were kept in the shed throughout the day provided with farm-grown chaffed green fodders ( APBN, CO-3 and 4, Super Napier, SSG and Hedge lucerne whichever available in the farm) in the morning and evening time, concentrate feed @ $1 \%$ of their body weight offered only in the evening time and not sent for grazing. The leftover fodder and feed was removed from the manger early morning every day and weighed for calculating amount of feed consumed by the animals. In G2 group, the lambs were sent for grazing for about 6 hours per day and offered an average of 125 grams of concentrate feed in the shed in the evening time. For the G3 group, the lambs were not offered any concentrate or supplemented feed in the shed and sent for grazing for 9 - 10 hours per day. The concentrate feed offered to the lambs in $\mathrm{G} 1$ and $\mathrm{G} 2$ group contain $\mathrm{CP}$ - 18 per cent, TDN - 72 Per cent.

The statistical significance of all bodyweight and BCS were analyzed as per the methods described by Snedecor and Cochran (1989).

\section{RESULTS AND DISCUSSION \\ Production Performance of lambs}

\section{Fortnightly body weight gain}

The overall mean body weight $(\mathrm{kg})$ gain of lambs in G1group was significantly $(P<0.01)$ higher than lambs reared in $G 2$ and G3 groups (Table 1). In intensive rearing system, the lambs were seldom exposed to harsh climatic conditions such as rain, cold and hot sun and this coupled with good plane of nutrition due to provision of chaffed succulent green forage and concentrate combination resulted in higher body weights as more nutrients were available for formation of muscle mass. In semi-intensive system, the growth rate were higher than extensive system due to supplementation with concentrate mixture apart from grazing.

The results of the present study were similar to the findings of Karthik et al. (2021) and Galmessa et al. (2002) who observed that the final body weight gain of lambs in concentrate supplemented group had significant $(\mathrm{P}<0.05)$ difference with only grazing animals group in Aged Horro sheep in Ethiopia. Pankaj (2010) in a study of 90 days on Marwari lambs found that the lambs supplemented with concentrate mixture of 1 per cent body weight had significantly higher body weight than non-supplemented group. Chaturvedi et al. (2010), Malisetty and Yerradoddi (2013), Jalajakshi et al. (2016) and Khanal et al. (2017) have also reported significantly $(\mathrm{P}<0.01)$ higher body weight gains with concentrate supplemented ram lambs than solely grazed lambs in extensive production system.

The results of the present study were in contradiction to the findings of Venkataramanan et al. (2015) who reported that the supplementation of 250 gram concentrate in addition to grazing did not have significant $(P<0.05)$ effect on body weight gain and Karim et al. (2007) have observed that total body weight gain $(\mathrm{kg})$ was higher in semi-intensive system followed by intensive feeding and extensive range management in Kheri lambs. 


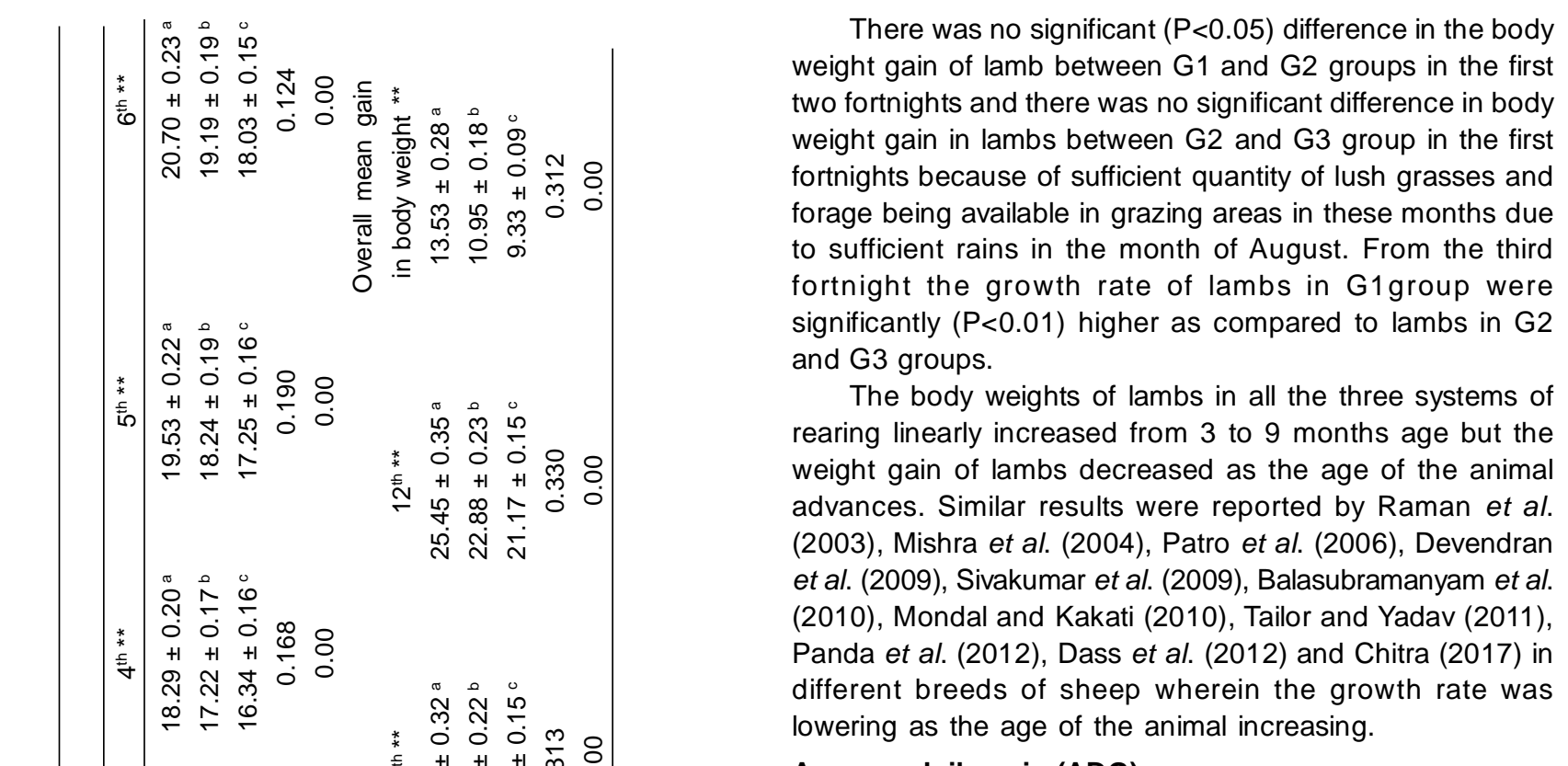


Production, Reproduction Performance and Cost Economics of Nellore Brown Lambs Reared under Different Systems of Rearing

Table 2: Fortnightly ADG (gm) of Nellore brown lambs from 3-9 months in different systems of rearing.

\begin{tabular}{|c|c|c|c|c|c|c|}
\hline \multirow{2}{*}{ Group } & \multicolumn{6}{|c|}{ Fortnights } \\
\hline & $1^{\text {st **}}$ & $2^{\text {nd } * *}$ & $3^{\text {rd } * *}$ & $4^{\text {th } * *}$ & $5^{\text {th } * *}$ & $6^{\text {th } * *}$ \\
\hline G1 & $120.56 \pm 2.09^{a}$ & $111.67 \pm 1.45^{\mathrm{a}}$ & $101.67 \pm 1.86^{a}$ & $90.56 \pm 1.73^{a}$ & $82.78 \pm 1.73^{a}$ & $72.92 \pm 3.55^{a}$ \\
\hline G2 & $102.22 \pm 2.22^{b}$ & $93.33 \pm 1.42^{b}$ & $82.78 \pm 1.29^{b}$ & $73.89 \pm 1.92^{b}$ & $68.33 \pm 1.67^{b}$ & $59.38 \pm 1.44^{b}$ \\
\hline G3 & $83.89 \pm 1.53^{c}$ & $80.00 \pm 1.42^{c}$ & $70.56 \pm 1.29^{c}$ & $65.56 \pm 1.98^{c}$ & $60.56 \pm 1.53^{c}$ & $48.44 \pm 1.12^{\circ}$ \\
\hline SEM & 2.76 & 2.34 & 2.32 & 2.05 & 1.81 & 2.13 \\
\hline \multirow[t]{2}{*}{$P$} & 0.00 & 0.00 & 0.00 & 0.00 & 0.00 & 0.00 \\
\hline & & Fortnights & & & & Overall mean \\
\hline $7^{\text {th } * *}$ & $8^{\text {th } * *}$ & $9^{\text {th } * *}$ & $10^{\text {th } * *}$ & $11^{\text {th } * *}$ & $12^{\text {th } * *}$ & $A D G$ ** \\
\hline $66.11 \pm 2.24^{a}$ & $61.67 \pm 3.08^{a}$ & $58.33 \pm 3.30^{a}$ & $50.00 \pm 1.53^{a}$ & $43.33 \pm 2.53^{a}$ & $37.22 \pm 2.39 a$ & $75.14 \pm 1.56$ \\
\hline $55.00 \pm 1.86^{b}$ & $50.56 \pm 1.92^{b}$ & $45.00 \pm 2.03^{b}$ & $36.67 \pm 1.74^{b}$ & $31.67 \pm 1.20^{b}$ & $27.22 \pm 1.53^{b}$ & $60.83 \pm 1.02^{b}$ \\
\hline $45.00 \pm 2.03^{c}$ & $38.33 \pm 1.45^{c}$ & $35.00 \pm 1.67^{c}$ & $32.44 \pm 4.45^{b}$ & $28.33 \pm 1.45^{b}$ & $23.33 \pm 1.54^{b}$ & $51.81 \pm 047^{c}$ \\
\hline 1.86 & 2.05 & 2.11 & 1.89 & 1.49 & 1.44 & 1.74 \\
\hline 0.00 & 0.00 & 0.00 & 0.007 & 0.00 & 0.00 & 0.00 \\
\hline
\end{tabular}

Means within a column having different superscripts differ significantly ${ }^{* *}(P<0.01),{ }^{*}(P<0.05)$.

G1 : Intensive system, G2 : Semi-Intensive system, G3 : Extensive system.

SEM : Standard error mean, $\mathrm{P}$ :Probability value.

Table 3: Cost economics of lambs in different systems of rearing.

\begin{tabular}{lccc}
\hline Particulars & G1 & G2 & G3 \\
\hline Expenditure & & & \\
Cost of animals & 39600 & 39600 & 39600 \\
Cost of green fodder & 4312 & - & - \\
Cost of concentrate feed & 9700 & 6300 & - \\
Cost of labour & 16200 & 16200 & 16200 \\
Cost of veterinary aid & 2050 & 2520 & 2520 \\
Cost of water and electricity & 1000 & 1000 & 1000 \\
Miscellaneous & 500 & 500 & 500 \\
Total expenditure & 73350 & 66120 & 59820 \\
Total recurring expenditure/ lamb & 2812.5 & 2210.0 & 1685 \\
Income & & & \\
Sale/ Value of lambs & 91800 & 81000 & 73428 \\
Sale of manure & 4000 & 2000 & 1000 \\
Gross income & 95800 & 83000 & 76960 \\
Net income & 22450 & 16880 & 14608 \\
Net income/lamb & 1870.8 & 1406.7 & 1217.33 \\
Cost / each live weight gain & 207.87 & 201.82 & 180.60 \\
Benefit cost ratio & $1.30: 1$ & $1.26: 1$ & $1.29: 1$ \\
\hline
\end{tabular}

G1: Intensive system, G2: Semi-Intensive system, G3: Extensive system.

in the three groups. The cost of animals was highest in the three groups followed by cost of labour (Table 3). The cost of concentrate feed was higher in the G1 group than G2 group because in G1 group, the lambs were provided with concentrate@1 per cent body weight. The cost of veterinary aid was same in the G2 and G3 groups and higher than G1 group because in G2 and G3 groups deworming was done two times more than $\mathrm{G} 1$ group. The cost of recurring expenditure was higher in G1 group followed by G2 and G3 group. These results were in agreement with Porwal et al. (2006), Devendran et al. (2012) and Shivakumara and Kiran (2019).
Major part of income is through sale of lambs in all three systems of rearing. The income from sale of manure was higher in G1 group than G2 and G3 group because lambs are in the sheds throughout day. The gross and net income was higher in G1 group followed by G2 and G3 group. Similar results were reported by Porwal et al. (2006), Pankaj et al. (2010) and Mahanthesh et al. (2019). The cost of per kg live weight was highest in G1 group than G2 and G3 group because of concentrate and fodder cost.

\section{CONCLUSION}

The body weight gain and average daily gain during the experiment period was higher in intensive system than a semi-intensive and extensive system of rearing but the cost of meat production was higher in the intensive system of rearing. The age at puberty and first service was lower in the intensive system because the ewe lambs gained higher body weight at earlier than other two systems of rearing.

\section{REFERENCES}

Arora, R., Kulkarni, V.S., Jain, A and Yadav, D.K. (2016). Yalaga sheep- A microsatellite based genetic profile. Indian Journal of Animal Sciences. 86: 1155-1158.

Arslan, M., Yılmaz, O. and Denk, H. (2018). A study on comparison of fattening performances and some slaughter characteristics of Suffolk and German Mutton Merino lambs under intensive fattening conditions. Indian Journal of Animal Research. 52(9): 1253-1256.

Balasubramanyam, D., Jaishankar, S. and Sivaselvam, S.N. (2010). Performance of Madras red sheep under farmer's flocks. The Indian Journal of Small Ruminants. 16(2): 217-220.

Bharambe, V.Y. and Burte, R. (2012). Comparative growth performance of deccani lambs under various rearing systems in Agro-ecological conditions of konkan. Indian Journal of Hill Farming. 25(1): 44-47. 
Chaturvedi, O.H., Mann, J.S and Karim, S.A. (2010). Effect of concentrate supplementation to ewes grazing on community rangeland during late gestation and early lactation. Indian Journal of Small Ruminants. 16(1): 97-100.

Chitra, R. (2017). Growth rate estimation for madras red ram under field condition. Shanlax International Journal of Veterinary Science. 4(4): 7-9.

Corner-Thomas, R.A., Ridler, A.L., Morris, S.T and Kenyon, P.R. (2015). Ewe lamb live weight and body condition scores affect reproductive rates in commercial flocks. New Zealand Journal of Agricultural Research. 58(1): 26-34.

Dass, G., Mandal, A., Rout, P.K and Roy, R. (2012). Rearing practices, morphological characteristics and growth performance of Muzaffarnagari sheep in its home tract. Indian Journal of Small Ruminants. 18(1): 37-40.

Dass, G., Dige, M.S and Rout, P.K. (2016). Factors affecting average daily weight gains (ADG) in Muzaffarnagari sheep. Indian Veterinary Journal. 93: 87-89.

Devendra, C. (1980). Potential of sheep and goats in less developed countries. Journal of Animal Science. 51(2): 461-473.

Devendran, P., Cauveri, D and Gajendran, K. (2009). Growth rate of Madras Red sheep in farmers' flocks. Indian Journal of Animal Research. 43(1): 53-55.

Devendran, P., Kandasamy, N., Panneerselvam, S. and Selvam, S. (2012). Economics of coimbatore sheep rearing. Indian Journal of Small Ruminants. 18(2): 239-243.

Galmessa, U., Abegaz, S., Dhuguma, G., Terefe, F., Aboma, G., Gizaw, S. and Prasad, S. (2002). Supplementary feeding of aged horro sheep in relation to weight gain, carcass yield and economic response under ethiopian conditions. Indian Journal of Small Ruminants. 8(2): 118-123.

Jalajakshi, K., Reddy, Y.R and Prasad, A.R.V. (2016). Growth performance and carcass traits of Nellore Brown ram lambs kept on grazing with or without concentrate supplementation. International Journal of Science Environment and Technology. 5(5): 2788-2797.

Jalajakshi, K., Reddy, Y.R. and Prasad, R.V. (2018). Effect of feeding sweet sorghum silage with or without supplementation on nutrient digestibilities and performance in Nellore brown ram lambs. Indian Journal of Animal Research. 52(5): 724-729.

Karim, S.A., Tripathi, M.K and Singh, V.K. (2007). Effect of varying levels of concentrate supplementation on growth performance and carcass traits of finisher lambs. Livestock Research for Rural Development. 19(11): 173-176.

Karthik, D., Suresh, J., Reddy, Y.R., Sharma, G.R.K., Ramana, J.V., Gangaraju, G. and Reddy, P.R.K. (2021). Farming systems in sheep rearing: Impact on growth and reproductive performance, nutrient digestibility, disease incidence and heat stress indices. Plos one. 16(1): e0244922.

Kenyon, P.R., Morris, S.T and West, D.M. (2010). Proportion of rams and the condition of ewe lambs at joining influences their breeding performance. Animal Production Science. 50(6): 454-459.

Khanal, B., Kabir, A.K.M.A., Baral, B.R and Dhakal, H.R. (2017). Growth and wool production of sheep reared at highland of Nepal. Bangladesh Journal of Animal Science. 46(3): 159-163.
Kochewad, S.A., Raghunandan, T., Rao, K.S., Reddy, K.K., Kumari, N.N., Ramana, D.B.V. and Singh, M. (2018). Productive performance, body condition score and carcass characteristics of Deccani lambs reared under different farming systems. Indian Journal of Animal Research. 52(3): 444-448.

Kumar, D.A.P., Prakash, M.G., Gupta, B.R., Raghunandan, T. and Chandra, A.S. (2017a). Average daily gain and Kleiber Ratio in Deccani Sheep. The Pharma Innovation. 6(6): 194-197.

Kumar, I.S., Gangaraju, G., Kumar, C.V. and Nath, S. (2018). Genetic parameters for growth rate and Kleiber ratios of Nellore sheep. Indian Journal of Animal Research. 52(10): 14051408.

Kumar, P.S., Vasanthakumar, P., Saravanajayam, M. and Balasubramaniam, A. (2017c). Effect of Various Levels of Concentrate Feed Supplementation on Birth Weight in Madras Red Sheep. Indian Veterinary Journal. 94(06): 19- 21.

Mahanthesh, M.T., Prasad, C.K., Barman, D., Nag, B.S., Ahirwar, M. and Narappa, G. (2019). Performance and economics of kenguri ram lambs under different rearing systems. Indian Journal of Animal Research. 53(7): 984-987.

Malisetty, V. and Yerradoddi, R.R. (2013). Effect of concentrate supplementation on growth and carcass characteristics in grazing ram lambs. International Journal of Food, Agriculture and Veterinary Sciences. 3(1): 43-48.

Mishra, P.K., Barik, N., Patro, B.N and Nayak, S. (2004). Production potentiality of Ganjam sheep under extensive management. Indian Journal of Small Ruminants. 10(2): 171-172.

Mondal, G. and Kakati, B.K. (2010). Body measurements and economic analysis of local sheep reared by farmers in Kargil. Indian Journal of Small Ruminants. 16(2): 240-242.

Ocak, S., Ogun, S. and Yilmaz, O. (2016). Dorper sheep utilizing feed resources efficiently: A Mediterranean case study. Revista Brasileira de Zootecnia. 45(8): 489-498.

Panda, P., Rao, P.K and Kumar, P. (2012). Performance of Edka sheep of Puri district of Odisha. Indian Journal of Small Ruminants. 18(2): 188-190.

Pankaj, L. (2010). Effect of concentrate supplementation on growth performance of lambs. Indian Journal of Small Ruminants. 16(2): 267-268.

Patro, B.N., Mallick, C.R., Rao, P.K and Panda, P. (2006). Production performance of indigenous meat type sheep in Kendrapada Distirct of coastal Orissa. Indian Journal of Small Ruminants. 12(1): 42-47.

Porwal, K., Karim, S.A., Sisodia, S.L. and Singh, V.K. (2006). Relative economics of lamb rearing for mutton production under extensive, semi intensive and intensive system of feeding management. Indian Journal of Small Ruminants. 12(1): 67-73.

Raman, K.S., Sundararaman, M.N., Haribhaskar, S. and Ganesakale, D. (2003). Biometrics and breed characteristics of Madras red sheep. Indian Journal of Small Ruminants. 9(1): 6-9.

Ramesh, D., Meena, H.R. and Meena, K.L. (2012). Analysis of Small ruminant market system in different agro-climatic zones of Southern India, Veterinary World. 5: 288-293. 
Production, Reproduction Performance and Cost Economics of Nellore Brown Lambs Reared under Different Systems of Rearing

Shivakumara, C. and Kiran, S. (2019). Economics of sheep and goat rearing under extensive, semi-intensive and intensive methods of rearing. Economic Affairs. 64(3): 553-561.

Sivakumar, T., Balasubramanyam, D., Jawahar, K., Gopi, H. and Jaishankar, S. (2009). Growth and reproductive performance of Madras Red sheep under field conditions. Indian Journal of Small Ruminants. 15(2): 248-252.

Snedecor G.W and Cochran W.G. (1989). Statistical Methods Oxford Publishing Company, Calcutta, India $6^{\text {th }}$ Edition.
Tailor, S.P and Yadav, C.M. (2011). Growth performance of preand post-weaning Sonadi lambs and adults in the native tract. Indian Journal of Small Ruminants. 17(2): 221-224.

Venkataramanan, R., Sreekumar, C., Manonnmani, G. Balasubramanyam, D. and Gopi, H. (2015). Effect of supplementary feeding of concentrate feed in Madras Red lambs under field conditions. Indian Journal of Small Ruminants. 21(1): 124-125. 